\title{
Content Translation And Validation Of The Pediatric PIV Infiltration Scale Into Brazilian Portuguese
}

\author{
Tradução e validação de conteúdo da Pediatric PIV Infiltration Scale para o português brasileiro \\ Traducción y validación del contenido de la Pediatric PIV Infiltration Scale para el portugués brasileño
}

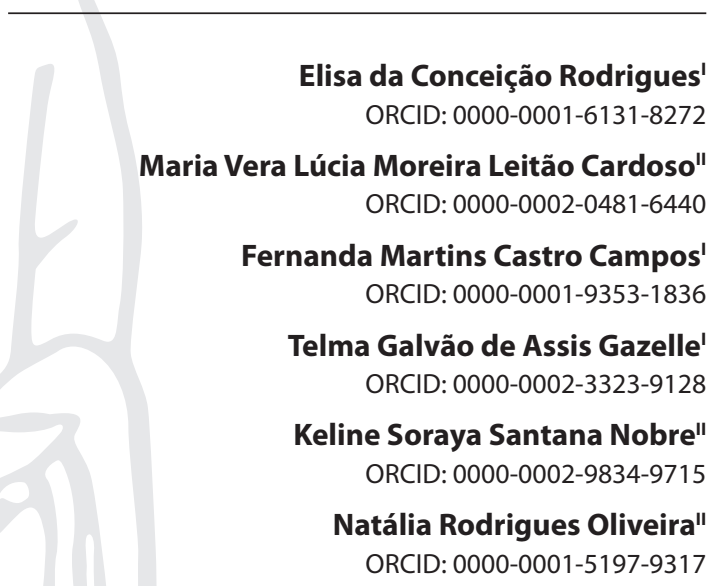

'Universidade Federal do Rio de Janeiro. Rio de Janeiro, Rio de Janeiro, Brasil.

"Universidade Federal do Ceará. Fortaleza, Ceará, Brasil.

How to cite this article:

Rodrigues EC, Cardoso MVLML, Campos FMC, Gazelle TGA, Nobre KSS, Oliveira NR. Content Translation And Validation Of The Pediatric PIV Infiltration Scale Into Brazilian Portuguese. Rev Bras Enferm. 2020;73(4):e20190300. doi: http://dx.doi.org/10.1590/0034-7167-2019-0300

\section{Corresponding author:}

Elisa da Conceição Rodrigues E-mail:elisadaconceicao@gmail.com

EDITOR IN CHIEF: Dulce Aparecida Barbosa ASSOCIATE EDITOR: Hugo Fernandes

Submission: 04-03-2019

Approval: 06-11-2019

\begin{abstract}
Objectives: to translate, adapt and validate the PIV Infiltration Scale content into Brazilian Portuguese. Methods: a methodological study. Initial translation was performed by two bilingual translators, translation synthesis; backtranslation to the original language; elaboration of the translated version and adapted by expert consensus; content validation and pretest. Results: the Pediatric PIV Infiltration Scale has been translated and adapted. Discrepancies were sorted out by consensus. The scale content was validated by nine experts, reaching a global content validity index of 0.95 . Pretest was performed by applying the scale to 33 intravenous device insertion sites of 17 newborns and 16 children. The predominant infiltration grades were 2 and 3. Conclusions: the Pediatric PIV Infiltration Scale's translated version achieved equivalence to Brazilian Portuguese and was validated by experts.

Descriptors: Intravenous Infusions; Neonatal Nursing; Pediatric Nursing; Translation; Validation Studies.
\end{abstract}

\section{RESUMO}

Objetivos: traduzir, adaptar e validar o conteúdo da PIV Infiltration Scale para o português brasileiro. Métodos: estudo metodológico. Foram realizadas tradução inicial por dois tradutores bilingues, síntese da tradução; tradução de volta ao idioma original; elaboração da versão traduzida e adaptada por consenso de especialistas; validação do conteúdo e préteste. Resultados: a Pediatric PIV Infiltration Scale foi traduzida e adaptada. As discrepâncias foram resolvidas por consenso. O conteúdo da escala foi validado por nove especialistas, alcançando índice global de validade de conteúdo de 0,95. O pré-teste foi realizado através da aplicação da escala em 33 locais de inserção de dispositivos intravenosos de 17 recémnascidos e 16 crianças. Os graus de infiltração predominantes foram o 2 e 3 . Conclusões: a versão traduzida da escala Pediatric PIV Infiltration Scale alcançou equivalência ao português brasileiro e foi validada por especialistas.

Descritores: Infusões Intravenosas; Enfermagem Neonatal; Enfermagem Pediátrica; Tradução; Estudos de Validação.

\section{RESUMEN}

Objetivos: traducir, adaptar y validar el contenido de la PIV Infiltration Scale al portugués brasileño. Métodos: estudio metodologico. La traducción inicial fue realizada por dos traductores bilingües, síntesis de traducción; traducción al idioma original; elaboración de la versión traducida y adaptada por consenso de expertos; validación de contenido y pretest. Resultados: la PIV Infiltration Scale pediátrica ha sido traducida y adaptada. Las discrepancias se resolvieron por consenso. El contenido de la escala fue validado por nueve expertos, alcanzando un índice de validez de contenido global de 0.95 . La prueba preliminar se realizó aplicando la escala a 33 sitios de inserción de dispositivos intravenosos de 17 recién nacidos y 16 niños. Los grados de infiltración predominantes fueron 2 y 3 . Conclusiones: la versión traducida de la PIV Infiltration Scale pediátrica logró equivalencia con el portugués brasileño y fue validada por expertos.

Descriptores: Infusiones Intravenosas; Enfermería Neonatal; Enfermería Pediátrica; Traducción; Estudios de Validación. 


\section{INTRODUCTION}

Children and newborns (NB) care, who need intravenous therapy, requires from nurses specific skills and knowledge such as anatomical and physiological characteristics, growth and development patterns, as well as developing care guidelines that support the practice ${ }^{(1)}$. From this perspective, it is essential that nurses use scientific evidence and technologies that guide a safe practice in the use of various types of intravenous devices.

Peripheral intravenous devices (PID) are routinely inserted into children to administer medication, fluids, and parenteral nutrition. Venipuncture is an extremely painful procedure and a stressful experience for NB, children and family. In this context of care, PID maintenance should follow protocols that promote venous access safety and durability for as long as possible.

A study about the meanings of the practice of intravenous therapy performed in a Neonatal Intensive Care Unit of the city of Rio de Janeiro showed that the predominant culture among professionals regarding intravenous therapy practice is still centered on PID insertion. There is little appreciation of protocols and guidelines for the maintenance of peripheral venous access. Such culture contributes to increased occurrence and severity of adverse events due to systematic surveillance deficiency of PID's insertion site during its permanence ${ }^{(2)}$. In this sense, the incorporation of new technologies directed to intravenous device site surveillance may contribute to culture change. It may also promote the reduction of adverse events that have potentially negative implications for patient safety, increased hospital stay, and health care costs ${ }^{(3)}$.

Infiltration is defined as inadvertent administration of non-vesicant solutions to adjacent tissues and leakage involves inadvertent administration of vesicant solutions, or IV fluid, which may cause tissue damage. The terms infiltration and extravasation are often used interchangeably, taking into account the difference between the types of solutions administered ${ }^{(1)}$. In this manuscript, the term infiltration was adopted according to the Pediatric PIV Infiltration Scale.

Infiltration is the most common adverse event in NB and children on peripheral intravenous therapy. National studies assessing the reasons for PID removal in NB and children concluded that infiltration was the most common peripheral intravenous therapy-related complication in this age group ${ }^{(4,-7)}$. A research conducted in neonatal units in southern Brazil showed that infiltration was the reason for PID removal in $69.89 \%$ of complications in 188 peripheral catheters ${ }^{(6)}$.

Depending on infiltration severity, patients may develop severe complications such as ulcerations, necrosis and compartment syndrome. Infiltration-related complications cause pain, suffering, length of stay, increased costs and may require reconstructive surgery ${ }^{(1)}$. NB and children have a higher risk of infiltration due to their limited ability to communicate and localize pain, decreased extravascular space on the scalp, and the back of the hands and feet. Other risk factors for infiltration in neonatal and pediatric patients are multiple peripheral venous punctures and venous network fragility ${ }^{(8)}$.

Constant surveillance of PID insertion site is critical to reduce the amount of volume inadvertently infused into the extravascular space and, consequently, the severity of this adverse event. Infusion Nursing Society (INS) standards for intravenous therapy practice recommend that infiltration assessment and treatment be based on institutional policies and guidelines that guide nursing practice. Nurses should assess the intravascular device's insertion site, determine the need and type of intervention, and record signs and symptoms regarding infiltration using standardized scales ${ }^{(8)}$.

A study conducted in Korea with 2,394 PID insertions in patients aged 0 to 19 years showed that using a scale to assess PID insertion site associated with other preventive measures dramatically reduced infiltration occurrence and infiltration ${ }^{(9)}$.

Several scales to assess infiltration are available in literature. However, there is a concern of the authors regarding the suitability of this technology for use in children and $\mathrm{NB}^{(1)}$. In this context, the Pediatric PIV Infiltration Scale ${ }^{(1)}$ was developed using the INS infiltration scale as a reference for the pediatric scale development.

The INS infiltration scale was reviewed by a group of experts from a US university pediatric hospital and was appropriate to the specific needs and characteristics of the pediatric population. The INS scale rating system was maintained, but clinical criteria were adjusted. The most important modification was the replacement of the centimeter measurement by the percentage in assessing the extent of edema of the affected limb.

The group of experts involved in the study considered the need to use the percentage because the measurement in centimeters is not suitable for children, especially preterm infants and NB, considering the reduced body size ${ }^{(1)}$. Thus, after adjustments, infiltration was classified in grids ranging from 0 to 4, resulting in the Pediatric PIV Infiltration Scale.

The scale was developed to be applied in PID insertion site assessment in NB and children and it is composed of four grading grades ( 0 to 4 ) that indicate the severity of the injury caused by infiltration. Infiltration severity is classified by the presence and extent of edema, other clinical signs, and ease or difficulty of infusion (Chart 3).

This scale can be used for PID insertion site assessment, according to institutional venous access surveillance protocols, production of nursing care quality indicators in intravenous therapy, and timely detection of infiltration preventing severe injury ${ }^{(1)}$.

Given the above, the translation, adaptation and validation of the scale and infiltration for use in pediatrics and neonatology, in the Brazilian context, may assist in the implementation of nursing guidelines aimed at surveillance and maintenance of peripheral venous access in children and NB. There are gaps in the translation, adaptation and validation studies of these scales in Brazil ${ }^{(7)}$.

The translated version needs to maintain semantic and idiomatic equivalence, besides being culturally and conceptually adapted in relation to the originally proposed tool. The process of translating and adapting tools developed in other languages saves time and financial resources, as well as comparing the results of studies conducted in different countries and regions ${ }^{(10)}$.

It is noteworthy that the production of knowledge about the methods for assessing infiltration in NB and children reflects the researchers' concern to determine s frequency, severity and variables associated with their occurrence, as well as the elaboration and assessment of care protocols to guide the practice. However, it is still scarce, particularly in the Brazilian setting ${ }^{(7)}$.

\section{OBJECTIVES}

To translate, adapt and validate the PIV Infiltration Scale content into Brazilian Portuguese. 


\section{METHODS}

\section{Ethical aspects}

The ethical aspects provided for in Resolution 466/12 of the Brazilian National Health Board (Conselho Nacional de Saúde) were respected. The original scale's author sent the authorization for translation and approval of the translated version by e-mail. The project was approved by the Research Ethics Committees of Universidade do Ceará and co-participating institutions, which issued favorable opinions of numbers 727.376 ; 770-893; 752-379; 783.797 e 938-796.

Participants from all stages of the research were informed about their objectives, risks and benefits and soon after signed the Informed Consent and the Informed Assent, when applicable.

\section{Study's design, place and period}

This is a methodological research on translation, cultural adaptation and tool validation, conducted at Universidade Federal do Ceará from April 2014 to March 2015. The study was conducted in two Pediatric Inpatient Units and two Neonatal Intensive Care Units based in the cities of Fortaleza and Rio de Janeiro.

\section{Population/sample; inclusion and exclusion criteria}

In the translation phase of the scale, an expert committee was formed whose criteria for inclusion in the study were: having clinical and/or research experience in neonatology, pediatrics and intravenous therapy, as well as fluency in English.

In the validation phase, a second expert committee was formed, whose inclusion criteria were to have clinical and/or child health research experience and intravenous therapy.

The pretest of the translated version of the Pediatric PIV Infiltration Scale was performed in NB and children by nurses from the Neonatal and Pediatric Units included in the study. The criteria for nurses to apply the scale in clinical practice were to act in direct care to patients and to have completed the four-hour training given by the researchers on the application of the scale in the assessment and surveillance of peripheral venous access.

The sample of NB and children included in the pretest was obtained by consecutive convenience, with a size defined between 30 and 40, as recommended by the translation and cultural adaptation protocol adopted ${ }^{(9)}$.The inclusion criteria of the patients in the study were aged 0-12 years and using a peripheral intravenous device with indication for removal by the medical or nursing staff. NB and children were excluded I use intravenous therapy only by central venous catheter.

\section{Study protocol - translation and validation}

The translation was performed according to an international protocol ${ }^{(11)}$ consisting of the steps: initial translation by two bilingual translators, synthesis of the two translations, backtranslation to the original language, elaboration of the translated version and adapted by expert consensus and testing of the translated version in clinical practice.

\section{Initial Translation (T1 and T2 production)}

The Pediatric PIV Infiltration Scale was independently translated by two bilingual and native Portuguese professional translators, one being informed about the purpose of the translation and the other not. Each translator produced a written translation report that included comments to highlight the terms or phrases that generated uncertainty and justifications for the final choices. At this time, translation 1 (T1) and translation 2 (T2) were produced.

\section{Synthesis of the two translations - T1 and T2 (T12 version production)}

The synthesis of the Portuguese translations of the first translator (T1) and the second (T2) was produced by the authors of the research, originating the version (T12). To elaborate the T12 version, the authors analyzed each item of the scale and reached a consensus on the discrepant items.

\section{Backtranslation to the original language (BT1 and BT2 versions production)}

The T12 version of the scale was backtranslated by two bilingual translators being one of them of English origin. The translators were not informed about the concepts explored on the scale and had no training in health. Backtranslation is a process of verifying the translated version validity intended to highlight gross inconsistencies or conceptual errors ${ }^{(11)}$.

\section{Elaboration of the translated version and adapted by expert consensus}

According to the inclusion criteria, the expert committee composed of three doctor nurses, one nurse member of the authors' research group and one of the translators, was established with the objective of consolidating all translated versions (T1, T2, T12, BT1, BT2), including the original scale, and develop the translated and adapted version into Portuguese.

The committee participants received by e-mail informed consent, a summary chart with all translated versions and the original scale, as well as a tool containing questions on semantic, idiomatic, cultural and conceptual equivalence. After signing the consent form and completing the analytical tool, the committee met to produce the translated and adapted Brazilian Portuguese version of the Pediatric PIV Infiltration Scale by consensus.

\section{Expert pre-final content validation}

In content validation, the researcher assesses if all relevant aspects of the object of study are included in the tool and if there are irrelevant items ${ }^{(12)}$.

Content validity is based on a judgment. There are no totally objective methods to ensure adequate coverage of the tool content, but it is increasingly common to use a group of independent experts to assess content validity. Overall, researchers calculate the content validity index $(\mathrm{CVI})$ that indicates the extent to which expert opinions are congruent ${ }^{(13)}$. 
The content of the translated scale was validated by a committee of nine expert nurses according to preestablished criteria. After analyzing scale content by experts, the CVI of each item and the scale as a whole (total CVI) were calculated. To calculate the $\mathrm{CVI}$ of the items separately, we used the formula $\mathrm{CVI}=$ number of answers 3 or 4 divided by the total number of answers.

For total CVI calculation, we added all CVI calculated separately and divided the result by the number of items considered in the assessment ${ }^{(13)}$.

\section{Pediatric PIV Infiltration Scale pre-final test}

Pretest data were collected using a tool containing the child identification data, the characteristics of intravenous therapy and the translated and adapted version of the Pediatric PIV Infiltration Scale. After parental and team authorization and child consent (where applicable), the following steps were followed for data collection: 1) preparation of children and family by nurses or nursing technicians for removal of the peripheral intravenous device in order to according to unit routine; 2 ) dressing removal from PID insertion site by nurses; 3) PID insertion site assessment by nurses trained to identify infiltration signs with Pediatric PIV Infiltration Scale and recording of information in the data collection tool. The scale can be applied in surveillance and assessment of peripheral venous access during its stay in the patient. However, it was chosen for its application at the time of device removal because the units participating in the study were not using transparent film type coverage at data collection. This would not allow viewing of PID insertion site.

\section{RESULTS}

For pre-final version formulation, discrepant terms between translations and semantic, idiomatic, cultural and conceptual equivalences were analyzed. The translators reported no difficulty in translating the scale from English into Portuguese. The backtranslations showed no major differences from the original version.

The discrepancies identified in the translation were related to scale title (Pediatric PIV Infiltration Scale) and terms grade, flushes ease, flushes with difficult, pain at site, skin cool to touch, blanching, redness, diminished pulse below site, skin breaking down and capillary refill (Chart 1).

The analysis of semantic, idiomatic, cultural and conceptual equivalence showed that the judge committee considered the translated scale version equivalent in most items (Chart 2).

\section{Content Validity Index}

Chart 3 shows the description of the translated, adapted and validated Pediatric PIV Infiltration content, with the respective ranks of infiltration grades. Tool's content analysis reached $\mathrm{CVI}=1$ in items 1.4 and 5 and 0.89 in items 2 and 4 , showing a high level of consensus among the judges. It was in relation to the scales' total $\mathrm{CVI}$ calculation, with $\mathrm{CVI}=0.95$.
Chart 1 - Consensus reached by the expert committee in the Pediatric PIV Infiltration Scale translations into Portuguese, Fortaleza, Ceará, Brazil, 2014

\begin{tabular}{|c|c|c|}
\hline $\begin{array}{l}\text { Original scale } \\
\text { term }\end{array}$ & Discrepant terms & Consensus \\
\hline $\begin{array}{l}\text { Pediatric PIV } \\
\text { Infiltration Scale }\end{array}$ & $\begin{array}{l}\text { Escala de infiltração } \\
\text { Intravenosa periférica } \\
\text { pediátrica } \\
\text { Escala pediátrica de } \\
\text { infiltração intravenosa }\end{array}$ & $\begin{array}{l}\text { "Escala Pediátrica } \\
\text { de Infiltração } \\
\text { Intravenosa } \\
\text { Periférica" }\end{array}$ \\
\hline Grade & $\begin{array}{l}\text { Graduação } \\
\text { Grau }\end{array}$ & Classificação \\
\hline $\begin{array}{l}\text { Flushes with } \\
\text { ease }\end{array}$ & $\begin{array}{l}\text { Flui bem } \\
\text { Flui com facilidade }\end{array}$ & $\begin{array}{l}\text { Flui com } \\
\text { facilidade }\end{array}$ \\
\hline $\begin{array}{l}\text { Flushes with } \\
\text { difficulty }\end{array}$ & $\begin{array}{l}\text { Raro rubor } \\
\text { Flui com dificuldade }\end{array}$ & $\begin{array}{l}\text { Flui com } \\
\text { dificuldade }\end{array}$ \\
\hline Pain at site & $\begin{array}{l}\text { Dor no local } \\
\text { Dor no local de infiltração }\end{array}$ & Dor no local \\
\hline $\begin{array}{l}\text { Skin cool to } \\
\text { touch }\end{array}$ & $\begin{array}{l}\text { Pele fria ao toque } \\
\text { Sensação de resfriamento } \\
\text { da pele ao toque }\end{array}$ & Pele fria ao toque \\
\hline Redness & $\begin{array}{l}\text { Vermelhidão } \\
\text { Hiperemia }\end{array}$ & Hiperemia \\
\hline Blanching & $\begin{array}{l}\text { Pele esbranquiçada } \\
\text { Palidez }\end{array}$ & Palidez no local \\
\hline $\begin{array}{l}\text { Diminished } \\
\text { pulse below site }\end{array}$ & $\begin{array}{l}\text { Pulso diminuído abaixo } \\
\text { do ponto }\end{array}$ & $\begin{array}{l}\text { Pulso diminuído } \\
\text { abaixo do local }\end{array}$ \\
\hline Skin breakdown & $\begin{array}{l}\text { Fissuras na pele } \\
\text { Ruptura da pele }\end{array}$ & Ruptura da pele \\
\hline $\begin{array}{l}\text { Capillary refill > } \\
4 \text { seconds }\end{array}$ & $\begin{array}{l}\text { Reenchimento capilar }> \\
4 \text { segundos } \\
\text { Enchimento capilar }> \\
4 \text { segundos }\end{array}$ & $\begin{array}{l}\text { Enchimento } \\
\text { capilar }> \\
4 \text { segundos }\end{array}$ \\
\hline
\end{tabular}

Note: PIV - Peripherally Inserted Intravenous

Chart 2 - Semantic, idiomatic, cultural and conceptual equivalence analysis of translations and suggestions from the judge committee, Fortaleza, Ceará, Brazil, 2014

\begin{tabular}{|l|l|l|l|l|l|}
\hline E1 & $\begin{array}{l}\text { Semantic } \\
\text { equivalence }\end{array}$ & $\begin{array}{l}\text { Idiomatic } \\
\text { equivalence }\end{array}$ & $\begin{array}{l}\text { Cultural } \\
\text { equivalence }\end{array}$ & $\begin{array}{l}\text { Conceptual } \\
\text { equivalence }\end{array}$ & $\begin{array}{l}\text { Change } \\
\text { suggestion }\end{array}$ \\
\hline E2 & Equivalent & $\begin{array}{l}\text { Partially } \\
\text { equivalent }\end{array}$ & Equivalent & $\begin{array}{l}\text { To translate } \\
\text { peripherally } \\
\text { inserted } \\
\text { intravenous } \\
\text { as Intravenosa } \\
\text { Periférica }\end{array}$ \\
\hline E3 & Equivalent & Equivalent & Equivalent & $\begin{array}{l}\text { Partially } \\
\text { equivalent }\end{array}$ & $\begin{array}{l}\text { To translate above } \\
\text { or below site as } \\
\text { acima or abaixo } \\
\text { place of insertion. }\end{array}$ \\
\hline E4 & Equivalent & Equivalent & Equivalent & Equivalent & Equivalent \\
\hline E5 & Equivalent & Equivalent & Equivalent \\
\hline
\end{tabular}


Chart 3 - Pre-final Pediatric PIV Infiltration Scale translated and validated, Fortaleza, Ceará, Brazil, 2015

\begin{tabular}{|c|c|}
\hline Classification & Characteristics \\
\hline Grau 0 & $\begin{array}{l}\text { Sem sintomas } \\
\text { Flui com facilidade }\end{array}$ \\
\hline Grau 1 & $\begin{array}{l}\text { Edema localizado (1\%-10\%) } \\
\text { Flui com dificuldade } \\
\text { Dor no local }\end{array}$ \\
\hline Grau 2 & $\begin{array}{l}\text { Edema leve } \\
\text { (até } 1 / 1 \text { ou de } 10 \% \text { a } 25 \% \text { da extremidade acima ou } \\
\text { abaixo do local de inserção) } \\
\text { Presença de hiperemia } \\
\text { Dorno local }\end{array}$ \\
\hline Grau 3 & $\begin{array}{l}\text { Edema moderado } \\
\text { ( } 1 / 4 \text { a } 1 / 2 \text {, ou de } 25 \%-50 \% \text { da extremidade acima ou } \\
\text { abaixo do local de inserção) } \\
\text { Dor no local } \\
\text { Pele fria ao toque } \\
\text { Palidez no local } \\
\text { Pulso diminuído abaixo do local }\end{array}$ \\
\hline Grau 4 & $\begin{array}{l}\text { Edema grave } \\
\text { (mais que } 1 / 2 \text { ou } 50 \% \text { da extremidade acima ou abaixo } \\
\text { do local de inserção) } \\
\text { Infiltração decorrente de infusão de } \\
\text { hemocomponentes, soluções irritantes ou vesicantes } \\
\text { (com edema de qualquer extensão) } \\
\text { Pele fria ao toque } \\
\text { Palidez no local } \\
\text { Ruptura da pele/necrose } \\
\text { Formação de bolhas } \\
\text { Pulso diminuído ou ausente } \\
\text { Dor no local } \\
\text { Enchimento capilar }>4 \text { segundos }\end{array}$ \\
\hline
\end{tabular}

Note: Pop's translation and adaptation (2012); PIV - Peripherally Inserted Intravenous.

\section{Pre-final test in clinical practice}

The pre-final stage of the pre-final version included six nurses, one nurse and two nurses from the Fortaleza units and three nurses from the Rio de Janeiro units. They were trained to apply the translated scale in clinical practice.

The pre-final version of the Pediatric PIV Infiltration Scale, translated and adapted into Brazilian Portuguese, was tested at 33 PID insertion sites in 33 patients (17 NB from the neonatal unit in Fortaleza, 08 children from the pediatric unit in Rio de Janeiro and 08 pediatric unit of Fortaleza). Seventeen children were male and sixteen female. Regarding age, 13 children were aged 0 to 14 days, eight between 29 days and 12 months, nine between 12 and 36 months and three over 36 months.

The scale was applied to NB and children with indication for PID removal. In $60.6 \%$ of the cases, there was indication for device removal due to complications; $33.3 \%$ at the end of the indication; $3.03 \%$ due to obstruction and $3.03 \%$ due to accidental loss. With regards to site, $33.3 \%$ of PID were in the right upper limb, $48.5 \%$ in the left upper limb and $18.2 \%$ in the right lower limb. After PID removal, the insertion site was assessed for clinical infiltration signs using the scale translated and validated into Brazilian Portuguese. Table 1 shows the clinical infiltration signs assessed through the scale listed by frequency of occurrence.
Table 2 lists the clinical signs related to the occurrence of infiltration in the sample studied.

Table 1 - Clinical infiltration signs of 33 PID insertion sites according to the translated and adapted version of the Pediatric PIV Infiltration Scale, Fortaleza, Ceará, Brazil, 2015

\begin{tabular}{ll}
\hline Variables & Fi \\
\hline Clinical Symptoms & \\
Sem sintomas & 11 \\
Flui com facilidade & 11 \\
Flui com dificuldade & 03 \\
Edema localizado & 05 \\
Edema leve & 03 \\
Edema moderado & 09 \\
Edema grave & 02 \\
Dor no local & 11 \\
Pele fria ao toque & 06 \\
Palidez no local & 07 \\
Pulso diminuído abaixo do local & 04 \\
Pulso diminuído ou ausente & 01 \\
Infiltração decorrente de infusão de hemocomponente & 01 \\
\hline Note: PID - Peripheral intravenous devices; PIV - Peripherally Inserted Intravenous.
\end{tabular}

Table 2 - Infiltration grades classification of 33 PIV insertion sites according to adapted version of the Pediatric PIV Infiltration Scale, Fortaleza, Ceará, Brazil, 2015

\begin{tabular}{lll}
\hline Variables & Fi & Fi\% \\
\hline $\begin{array}{l}\text { Infiltration Grade } \\
\text { Grau 0 }\end{array}$ & \\
Grau 1 & 11 & 33,4 \\
Grau 2 & 05 & 15,1 \\
Grau 3 & 06 & 18,2 \\
Grau 4 & 09 & 27,2 \\
\hline Note: PIV-Peripherally Inserted Intravenous. & 02 & 6,1 \\
\hline
\end{tabular}

\section{DISCUSSION}

During the Pediatric PIV Infiltration Scale translation and validation process, the steps proposed by the chosen method were strictly followed ${ }^{(11)}$, which has been used by several authors in translation and adaptation of questionnaires and scales in Brazil(10,14-17).

The authors did not mention difficulties in the translation and backtranslation steps of the Pediatric PIV Infiltration Scale, corroborating the study of translation and cultural adaptation of the Premature Infant Pain Profile scale. No difficulties were identified either, since the two scales are composed of technical terms and assess objective parameters and not psychosocial phenomena, which contributes to the cultural approximation of the language ${ }^{(10)}$.

The discrepant terms in the translations were discussed by the consensus committee of experts taking into consideration the most appropriate term for expressing signs and clinical infiltration signs and semantic similarity with Brazilian Portuguese.

Assessing the psychometric properties of tools is essential to determine whether the tool is suitable for use in the adapted cultural context, as well as meeting its proposed objectives ${ }^{(15)}$.

Content validity is an important phase in the development and adaptation of questionnaires and scales $^{(13)}$. Thus, content validity was considered through judgment by CVI calculation.

The translated and adapted content of the Pediatric PIV Infiltration Scale achieved a high level of consensus among judges, both in 
the separate items and in the whole scale where CVI was 0.95 (Chart 3). In a study of translation and cultural adaptation of the Pediatric PIV Infiltration Scale developed in Turkey, with 54 NB, the authors obtained $\mathrm{CVI}=0.99$ in tool content assessment by seven judges ${ }^{(18)}$.

Table 2 shows the classification of the infiltration grades assessed according to the Pediatric PIV Infiltration Scale. Infiltration was classified in grades ranging from 0 to 4 according to the translated and adapted scale. There is a predominance of grades 0 (33.4), 3 (27.2\%), 2 (18.2\%) 1 (15.1\%) and 4 (6.1\%). 66.6\% of the children assessed presented infiltration signs by adding the grades 1, 23 and 4. National and international studies with children concluded that infiltration was the most frequent complication in this age group $^{(4-5)}$. Thus, there is a need for nursing interventions that prevent and early detect infiltration avoiding the aggravation of injuries.

Infiltration was classified into grades ranging from 0 to 4 according to the translated and adapted Pediatric PIV Infiltration Scale pre-final version (Chart 3). Implementation of care protocols that include PID insertion site assessment may reduce the rates and severity of infiltration injury when it is still detected in grades 1 and $2^{(7,19)}$.

The most frequent clinical infiltration signs were edema and pain at PID insertion site. It is important to highlight that pain is the clinical sign present in all grades of the scale (1 to 4), being the earliest infiltration sign. Therefore, PID insertion site assessment through the Pediatric PIV Infiltration Scale leads the professional to question venous access permeability and infiltration in the presence of local pain, indicating PID removal before the injury becomes more severe as demonstrated in the Turkish scale validation study ${ }^{(18)}$. However, there is a gap in the literature regarding the incidence of different clinical infiltration signs from the assessment by pediatric scales.

A study conducted in 10 pediatric hospitals in the United Kingdom highlighted the professionals' perceptions on extravasation clinical management, evidencing the lack of guidelines for assessing the severity of the lesions. The authors highlight the need to increase professionals' awareness of the great potential for extravasation injury-related morbidities and to conduct further studies to establish best practices ${ }^{(20)}$.

It is noteworthy that until the completion of this manuscript no translation or validation studies of the Pediatric PIV Infiltration Scale were found in Brazil or into Brazilian Portuguese.

\section{Study limitations}

Although studies have shown good consensus among evaluators, while using the Pediatric PIV Infiltration Scale in English and Turkish ${ }^{(1,18)}$, we suggest that further studies be conducted to assess the consensus among evaluators in the Brazilian Portuguese version.

\section{Contributions to nursing and health}

This study provides a useful tool for improving safety of peripheral intravenous device use in NB and children. This technology may be incorporated into clinical protocols for prevention and treatment of infiltration in this clientele.

\section{CONCLUSIONS}

The Pediatric PIV Infiltration Scale has been translated and culturally adapted into Brazilian Portuguese and its content has been validated by experts. At the end of pretest, no difficulties were reported in the scale use by nurses and no changes in the translated and adapted version were suggested. Other studies that apply the scale in the Brazilian context are recommended and allow other validations regarding psychometric properties.

\section{ACKNOWLEDGMENTS}

A special thanks to the Brazilian National Council for Scientific and Technological Development (Conselho Nacional de Desenvolvimento Científico e Tecnológico).

\section{REFERENCES}

1. Pop RS, Pediatric peripheral intravenous infiltration assessment tool. J Infus Nurs. 2012;35(4):243-8. doi: 10.1097/NAN.0b013e31825af323

2. Rodrigues EC, Cunha SR, Gomes R. The vein is missed: meanings of intravenous therapy practice in Neonatal Intensive Care Unit. Ciênc Saúde Coletiva. 2012;17(4):989-99. doi: 10.1590/S1413-81232012000400021

3. Taylor JT. Implementing an evidence-based practice project in the prevention of peripheral intravenous site infiltrations in children. J Infus Nurs. 2015;38(6):430-5. doi: 10.1097/NAN.0000000000000131

4. Gomes ACR, Silva CAG, Gamarra CJ, Faria JCO, Avelar AFM, Rodrigues EC. Assessment of phlebitis, infiltration and extravasation events in neonates submitted to intravenous therapy. Esc Anna Nery. 2011;15(3):472-9. doi: 10.1590/S1414-81452011000300005

5. Lima-Jacinto AK, Avelar AFM, Pedreira MLG. Predisposing Factors for Infiltration in Children Submitted to Peripheral Venous Catheterization. J Infus Nurs. 2011;34(6):391-8. doi: 10.1097/NAN.0b013e3182306491

6. Danski MTR, Mingorance P, Johann DA, Vayego SA, Lind J. Incidence of local complications and risk factors associated with peripheral intravenous catheter in neonates. Rev Esc Enferm USP. 2016;50(1):22-8. doi: 10.1590/S0080-623420160000100003

7. Rodrigues EC, Cardoso MVLML, Campos FMC, Gazelle TGA, Oliveira NR. Infiltration related to peripheral intravenous therapy in newborns and children: integrative review Rev Soc Bras Enferm Ped [Internet]. 2017[cited 2018 Aug 27];17(2):83-90. Available from: https://sobep.org. $\mathrm{br} /$ revista/component/zine/article/241-infiltracao-relacionada-a-terapia-intravenosa-periferica-em-recem-nascidos-e-criancas-revisaointegrativa.pdf

8. Infusion Nursing Society. Infusion therapy standards of practice. J Infus Nurs. 2016;39(1 Suppl). doi: 10.1097/NHH.0000000000000481 
9. Park SM, Jeong IS, Kim KL, Park KJ, Jung MJ, Jun SS. The Effect of Intravenous Infiltration Management Program for Hospitalized Children. J Pediatric Nurs. 2016;31(2):172-8. doi: 10.1016/j.pedn.2015.10.013

10. Bueno M, Costa, Oliveira AAS, Cardoso R, Kimura AF. Translation and adaptation of the premature infant pain profile into Brazilian Portuguese. Texto Contexto Enferm. 2013;22(1):29-35. doi: 10.1590/S0104-07072013000100004

11. Beaton DE, Bombardier C, Guillemin F, Ferraz MB. Recommendations for the Cross-Cultural Adaptation of the DASH \& Quick DASH Outcome Measures. American Academy of Orthopaedic Surgeons and Institute for Work \& Health [Internet]. 2007[cited 2018 Aug 27];01-45. Available from: http://www.dash.iwh.on.ca/sites/dash/files/downloads/cross_cultural_adaptation_2007.pdf

12. Soares MH, Luís MAV, Hirata AGP. Cross-cultural cultural adaptation of the "Nursing Students' Attitudes Toward Mental Health Nursing and Consumers" in Brazil. Rev Bras Enferm. 2015;68(2):198-205. doi: 10.1590/0034-7167.2015680203i

13. Alexandre NMC, Coluci MZO. Validade de conteúdo nos processos de construção e adaptação de instrumentos de medidas. Ciênc Saúde Coletiva. 2011;16(7):3061-8. doi: 10.1590/S1413-81232011000800006

14. Stacciarini TSG, Pace AE. Tradução, adaptação e validação de uma escala para o autocuidado de portadores de diabetes mellitus tipo 2 em uso de insulina. Acta Paul Enferm. 2014;27(3):221-9. doi: 10.1590/1982-0194201400038

15. Coster WJ, Mancini MC. Recommendations for translation and cross-cultural adaptation of instruments for occupational therapy research and practice. Rev Ter Ocup Univ. São Paulo. 2015;26(1):50-7. doi: 10.11606/issn.2238-6149.v26i1 p50-57

16. Rocha EA, Alexandre NMC, Silva JV. Cultural adaptation and validation of the Freiburg Life Quality Assessment - Wound Module to Brazilian Portuguese. Rev Latino-Aam Enfermagem. 2016;24:e2684. doi: 10.1590/1518-8345.0289.2684

17. Borsa JC, Damásio BF, Bandeira DR. Adaptação e validação de instrumentos psicológicos entre culturas: algumas considerações. Paidéia, 2012;22(53):423-2. doi: 10.1590/S0103-863X2012000300014

18. Ebru T, Ozlem E, Ayşe K, Şengul C, Guner K, Fahri O. Turkish validity reliability of the pediatric peripheral intravenous infiltration scale and its adaptation to newborn. J Pediatr Res. 2017;4(4):232-8. doi: 10.4274/jpr.78055

19. Warren D. Implementation of a protocol for the prevention and management of extravasation injuries in the neonatal intensive care patient. Int J Evid Based Healthc. 2011;9(2):165-71. doi: 10.1111/j.1744-1609.2011.00213.x

20. Ching D, Wong KY. Pediatric extravasation injury management: a survey comparing 10 hospitals. Pediatr Neonatol. 2017;58(6):549-551. doi: 10.1016/j.pedneo.2016.09.006 